their exact separation and determination extremely difficult. The quantity of these undetermined bodies in cereal grains is very minute. In stalks and straw, and other bodies containing a large excess of ligno-cellulose compounds, this quantity is doubtless much larger.

[CONTRIBCTIONS FROM THE CHEMICAL LABORATORY OF THE U. S DEPARTMENT OF AGRICULTURE, No. 3I.]

\title{
THE SOLUBILITY OF THE PENTOSANS IN THE REA- GENTS EMPLOYED IN THE ESTIMATION OF STARCH.
}

\author{
BY W. H. KRUG AXr H. W. WILEr,1 \\ Received February 15,1898
}

$\mathrm{HE}$ methods which have been generally adopted for the
quantitative determination of starch in a cereal or fodder are based on one or two principles; viz., the application of high pressure in contact with water containing some organic acid, to prevent the decomposition of the sugars formed during the hydrolysis, or the conversion of the starch by means of diastase. The results obtained by the former methods are always a little too high and do not represent the actual starch content of the material under examination. In analytical work where it is desired to obtain the exact percentage of starch, diastase must be used and the application of any acid avoided until those bodies which may be acted upon by it have been removed by filtration, or else a correction must be applied as described in our preceding paper. The increased amount of starch found by the use of high pressure methods is due to the action of the organic acid on the pentosans and hemicelluloses present which results in the formation of reducing substances.

We have determined the amount of pentosans dissolved in the application of these methods with the following results:

I. Solubility of the pentosans by digesting for two and onehalf hours at three and one-half atmospheres with thirty cc. of water and twenty-five cc. of one per cent. lactic acid:

\begin{tabular}{|c|c|c|c|}
\hline \multirow[b]{2}{*}{ Substance. } & \multirow{2}{*}{$\begin{array}{l}\text { Per cent. of } \\
\text { pentosans ins } \\
\text { substance. }\end{array}$} & \multicolumn{2}{|c|}{ Petutosans dissolved. } \\
\hline & & $\begin{array}{c}\text { In per cent. of } \\
\text { substance. }\end{array}$ & $\begin{array}{l}\text { In percent. of } \\
\text { pentosans. }\end{array}$ \\
\hline Whea & . 5.80 & $4.6_{3}$ & $79.8_{3}$ \\
\hline Wheat ? & .5 .17 & 4.66 & 90.13 \\
\hline
\end{tabular}

1 Read before the American Chemical Society and Section $C$ of the American Association for the Advancement of Scietice, at Detroit, August I2, 1897. 
2. Solubility of pentosans by digesting for two and one-half hours at three and one-half atmospheres with fifty-five $\mathrm{cc}$. of water and five-tenths gram salicylic acid:

\begin{tabular}{|c|c|c|c|}
\hline \multirow[b]{2}{*}{ Substance. } & \multirow{2}{*}{$\begin{array}{l}\text { Per cent. of } \\
\text { pentosans in } \\
\text { substance. }\end{array}$} & \multicolumn{2}{|r|}{ issolved } \\
\hline & & $\begin{array}{l}\text { In per cent. of } \\
\text { substance. }\end{array}$ & $\begin{array}{l}\text { In per cent. of } \\
\text { pentosans. }\end{array}$ \\
\hline Whea & ... 5.80 & 4.5 & 78.27 \\
\hline Wheat & ... 5.I7 & 4.08 & 78.91 \\
\hline
\end{tabular}

The pentosans which had gone into solution were determined by diluting the liquid to $250 \mathrm{cc}$. after cooling, filtering, and distilling roo cc. of the filtrate with twelve per cent. hydrochloric acid until no furfural could be detected in the distillate. The furfural was precipitated with phenylhydrazin acetate in the usual manner.

$\mathrm{J}$. König, in an article on the methods of analysis used in the examination of fodders published in Landwirthschaftlichen Versuchs-Stationen, 48, 8I, states that diastase also acts as a solvent for pentosans and hemicelluloses and gives the following figures:

\begin{tabular}{|c|c|c|c|}
\hline Substance. & $\begin{array}{l}\text { Per cent. of } \\
\text { pentosans in } \\
\text { substance. }\end{array}$ & $\begin{array}{l}\text { Pentosans dis } \\
\text { In per cent. of } \\
\text { substauce. }\end{array}$ & $\begin{array}{l}\text { ed by diastase. } \\
\text { In per cent. of } \\
\text { pentosans. }\end{array}$ \\
\hline Rye............... & .. 8.90 & 2.22 & 24.95 \\
\hline Peas............ & . 3.62 & 1.02 & 28. I 7 \\
\hline Potatoes ........... & .. 2.12 & 0.94 & $44 \cdot 34$ \\
\hline Rye straw......... & .. 18.07 & 2.74 & I5.22 \\
\hline Pea straw ......... & .. 10.27 & 1.85 & I8. II \\
\hline
\end{tabular}

If this were true, it would render the diastase method fully as unreliable as the high pressure methods and the problem of determining the exact starch content of a material would be as far from solution as ever. We therefore decided to investigate this point with the following results:

Solubility of pentosans by digesting with thirty cc. malt extract (roo grams malt to one liter of water) until all starch had been converted:

\begin{tabular}{|c|c|c|c|}
\hline Substance. & $\begin{array}{l}\text { Per cent. of } \\
\text { pentosans in } \\
\text { substance. }\end{array}$ & \multicolumn{2}{|c|}{$\begin{array}{l}\text { Pentosans dissolved by malt diastase. } \\
\text { In per cent. of } \\
\text { substance. }\end{array}$} \\
\hline Wheat ........... & .. 5.80 & 0.011 & $0.18 \mathrm{I}$ \\
\hline Barley........ & .. 6.50 & 0.010 & $0.15 \mathrm{I}$ \\
\hline \multirow[t]{2}{*}{ Rye $\ldots \ldots \ldots \ldots$. } & .. 8.10 & 0.016 & 0.195 \\
\hline & & 0.017 & 0.206 \\
\hline \multirow{2}{*}{\multicolumn{2}{|c|}{ Oats $\ldots \ldots \ldots \ldots \ldots \ldots$ I 3.65}} & o.oto & $0.07 I$ \\
\hline & & 0.010 & $0.07 \mathrm{I}$ \\
\hline
\end{tabular}


Solubility of pentosans by digesting with five-tenths gram taka-diastase until all starch had been converted:

\begin{tabular}{|c|c|c|c|}
\hline \multirow{2}{*}{ Substance. } & \multirow{2}{*}{$\begin{array}{l}\text { Percent. of } \\
\text { pentosans in } \\
\text { substance. }\end{array}$} & \multicolumn{2}{|c|}{ Pentosans dissolved. } \\
\hline & & $\begin{array}{l}\text { In per cent. of } \\
\text { substance. }\end{array}$ & $\begin{array}{l}\text { In per cent. of } \\
\text { pentosans. }\end{array}$ \\
\hline \multirow[t]{2}{*}{ Wheat.... } & . 5.80 & 0.011 & 0.194 \\
\hline & & 0.012 & 0.199 \\
\hline Barley ........... & .. 6.50 & 0.015 & 0.238 \\
\hline Rye............. & . 8.10 & 0.017 & 0.209 \\
\hline 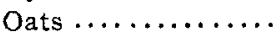 & $\ldots I_{3} .65$ & $0.01 \mathrm{I}$ & 0.079 \\
\hline
\end{tabular}

The small amounts of pentosans found here are, without doubt, not due to any solvent action of the diastase on the pentosans as it is well known that soluble starch, dextrin, sucrose, and all hexoses will yield small amounts of furfural when distilled with twelve per cent. hydroctloric acid. We are therefore justified in assuming that diastase has no solvent action on the pentosans and is a reliable means for determining the exact starch content of a cereal or fodder.

\section{A NEW ELECTROLYTIC STAND.}

By GEORgE J. HOLGH.

Received February $3,18 \mathrm{~g} 8$.

THE electrolytic stand herein described was devised and made by myself, and is, as I believe, an entire novelty. It is very simple and easy of construction, and anyone with a little knowledge of tools can make it for himself.

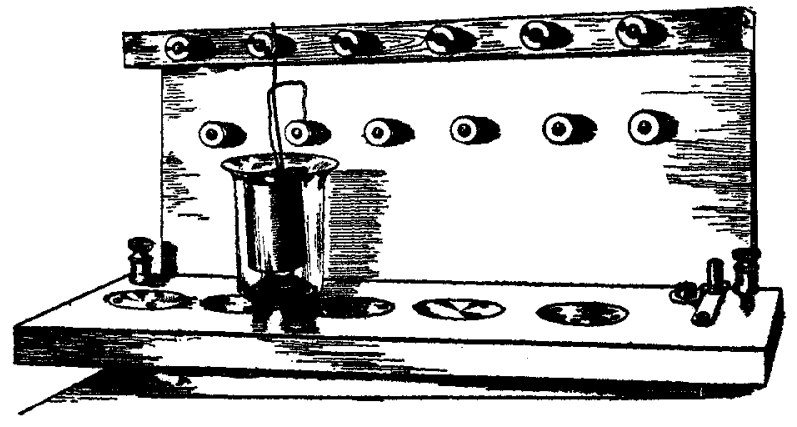

By arranging on an upright board a double series of binding posts for the attachment of the electrodes, and also by the use of a number of copper disks in the base of the stand for direct con- 